\title{
Biomethanation of Carpet Grass (Axonopus fissifolius)
}

\author{
Chima Ngumah, Jude Ogbulie, Justina Orji and Ekperechi Amadi
}

Department of Microbiology, Federal University of Technology, Nigeria

cross $^{\text {ref }}$ http://dx.doi.org/10.5755/j01.erem.66.4.5228

(Received in September, 2013; accepted in December, 2013)

\begin{abstract}
Axonopus fissifolius commonly called "carpet grass" was subjected to anaerobic digestion for 30 days. Anaerobic digestion was carried out in a batch-fed process at the ambient temperature of $27-29^{\circ} \mathrm{C}$ Biomethane measurements were obtained by measuring the volume displacement of a saturated filtered calcium hydroxide solution in a transparent calibrated vessel. $42.7 \mathrm{~g}$ of fresh carpet grass clippings yielded $1.955 \mathrm{~L}$ of biomethane. Biomethane potential (BMP) of carpet grass for a 30 day anaerobic digestion was $0.05 \mathrm{~m}^{3} \mathrm{CH}_{4} \mathrm{~kg}^{-1} \mathrm{TS}$. The rates of biomethane potentials for the first, second, third, fourth and fifth six-day intervals were $1.5 \mathrm{~mL} \mathrm{~g}^{-1} \mathrm{TS}(2.81 \%), 6.4 \mathrm{~mL} \mathrm{~g}^{-1} \mathrm{TS}(14.58 \%), 16.1 \mathrm{~mL} \mathrm{~g}^{-1} \mathrm{TS}(30.18 \%), 17.74 \mathrm{~mL} \mathrm{~g}^{-1}$ TS $(33.25 \%)$, and $10.23 \mathrm{~mL} \mathrm{~g}^{-1}$ TS $(19.81 \%)$ respectively. The total solids, volatile solids and $\mathrm{pH}$ of feedstock and digestate were $85.80 \%$ and $85.56 \%, 90.91 \%$ and $87.58 \%, 6.6\left(27^{\circ} \mathrm{C}\right)$ and $6.9\left(27^{\circ} \mathrm{C}\right)$ respectively. The relatively high biomethane potential of carpet grass at the ambient temperature presented in this paper depicts anaerobic digestion as a viable means of profitably treating grass waste for both sanitation and generating biomethane especially in the tropics where the ambient temperatures are usually favourable for optimum biomethanation for most part of the year, thus making the process affordable and less cumbersome.
\end{abstract}

Keywords: Renewable energy, anaerobic digestion, grass waste, biogas

\section{Introduction}

Biomass waste is the most common feedstock of biomethanation, with biomethanation itself being the most suitable and mature technology to convert biowaste to bioenergy ( $\mathrm{Yu}$ et al. 2010). Biogas produced from biowaste is comparatively competitive, in terms of efficiency and cost, with other bioenergy forms (Edelmann et al. 2000; Chynoweth et al. 2001). This is basically due to the fact that biomass is the nature's preferred method of solar energy storage; thus providing a wide range of substrates for biomethanation- wood, food waste, energy crops and grass (Abu-Dahrieh et al. 2011).

Grasslands play an important role in global agriculture, covering about $69 \%$ (3.4 billion hectares) of the world's agricultural area or $26 \%$ of the total land area (FAOSTAT 2008). In the last two decades considerations on grassland use for bioenergy have considerably increased in Europe and North America (McLaughlin et al. 2002; Murphy and Power 2008). Grassland biomass is suitable for bioenergy production, and this has been corroborated by many researchers (Walsh et al. 2003; Thran 2005; Prochnow et al. 2008).

Considering limited availability of farmland and rising demand for agricultural products, biomass production for energy purposes on arable land will unfavourably compete with food production (Pick et al. 2012). Consequently, this study highlights the biomass potentials associated with "green waste" from residual grasslands currently not used for agricultural purposes: roadside edges, conservation grasslands, riparian stretches along ditches and streams and municipal green belts (public lawns, parks and sports fields). In Nigeria, these "green resources" are often times left overgrown and unkempt, and even when mowed the "green waste" is usually left in situ to rot. The grass studied in this work is carpet grass (Axonopus fissifolius). Harnessing herbaceous biomass as substrate for anaerobic digestion for biogas and biofertiliser production presents a profitable duo resource management/resource recovery platform - solid waste 
management, biogas and biofertiliser recovery, not mentioning job creation and other allied benefits.

\section{Methods}

Sample collection and processing: Fresh grass clippings were collected immediately after mowing from a residential lawn in Owerri city (Nigeria).

Preparation of feedstock: About $42.7 \mathrm{~g}$ of fresh carpet grass cuttings were seeped in $530 \mathrm{~mL}$ untreated tap water. This was then inoculated with $10 \mathrm{~mL}$ digestate from beef cattle gastro-intestinal content anaerobic digestion.

Experimental set-up: The feedstock preparation was placed in a batch reactor operated at the ambient temperature of $27-29^{\circ} \mathrm{C}$ for a retention period of 30 days. The candle jar method described by Jensen and Trager (1977) was used to achieve anaerobiosis. The batch reactor was stirred manually by gently shaking or swirling it three to five times daily. Experiments were carried out in triplicates.

Collection of gas samples: Using the modified method of Nda-Umar and Uzowuru (2011), biogas and biomethane samples were collected and measured daily. Biogas generation was measured by rapidly measuring the volume displacement of a clear solution of filtered saturated calcium hydroxide solution $(2 \mathrm{~g} / \mathrm{L})$ in a transparent calibrated vessel, when the gas sample was rapidly bubbled through it. The residual displacement after the gas had stood for 24 hours in the calcium hydroxide solution chamber was taken as the biomethane content.

Physicochemical analysis: The temperature was measured using a mercury thermometer (range, 0 $110^{\circ} \mathrm{C}$ ) and $\mathrm{pH}$ determined with a Hanna Instrument pH meter (Model: H196107). Total solids (TS) and volatile solids (VS) were determined using standard procedures given by Pillai (2009).

Data analysis: Data generated were the averages of the triplicate readings from the experiments. Graphs were generated using the Microsoft Excel 2003 software.

\section{Results and Discussion}

Figure 1 shows daily readings of biogas yields and their biomethane contents. Though there were indications of biogas production from day 3, biogas reading was started from day 6. Daily biogas yield steadily increased from the ninth day to the sixteenth day of anaerobic digestion (AD) when it reached its maximum. The cumulative biogas and biomethane yields were $74.05 \mathrm{~mL} \mathrm{~g}^{-1} \mathrm{TS}$ and $59.83 \mathrm{~mL} \mathrm{~g}^{-1} \mathrm{TS}$ respectively, while the average biomethane content of biogas was $80.79 \%$. The average daily yield of biogas and biomethane for 30 day $\mathrm{AD}$ was estimated to be $2.2 \mathrm{~mL} \mathrm{~g}^{-1}$ day $^{-1} \mathrm{TS}$ and $1.78 \mathrm{~mL} \mathrm{~g}^{-1}$ day $^{-1} \mathrm{TS}$ respectively. The rates of biomethane potentials for the first, second, third, fourth and fifth six-day intervals were $1.5 \mathrm{~mL} \mathrm{~g}^{-1} \mathrm{TS}(2.81 \%), 6.4 \mathrm{~mL} \mathrm{~g}^{-1} \mathrm{TS}$ (14.58\%), $16.1 \mathrm{~mL} \mathrm{~g}^{-1}$ TS $(30.18 \%), 17.74 \mathrm{~mL} \mathrm{~g}^{-1} \mathrm{TS}$ (33.25\%), and $10.23 \mathrm{~mL} \mathrm{~g}^{-1} \mathrm{TS}(19.81 \%)$ respectively. Using the schemes of the Biogas Project, LGED (http://api.ning.com), a 120 day $\mathrm{AD}$ of Axonopus fissifolius would give a cumulative yield of approximately $370.25 \mathrm{~mL} \mathrm{~g}^{-1} \mathrm{TS}$ and $299.15 \mathrm{~mL} \mathrm{~g}^{-1} \mathrm{TS}$ of biogas and biomethane respectively. This is similar to the figures given by Al Seadi et al. (2008) and Deublein and Steinhauser (2008). Disparity in actual yield is however bound to occur due to the type or species of crop/plant/grass used as substrate (DeRenzo 1997; Kumar 2012).

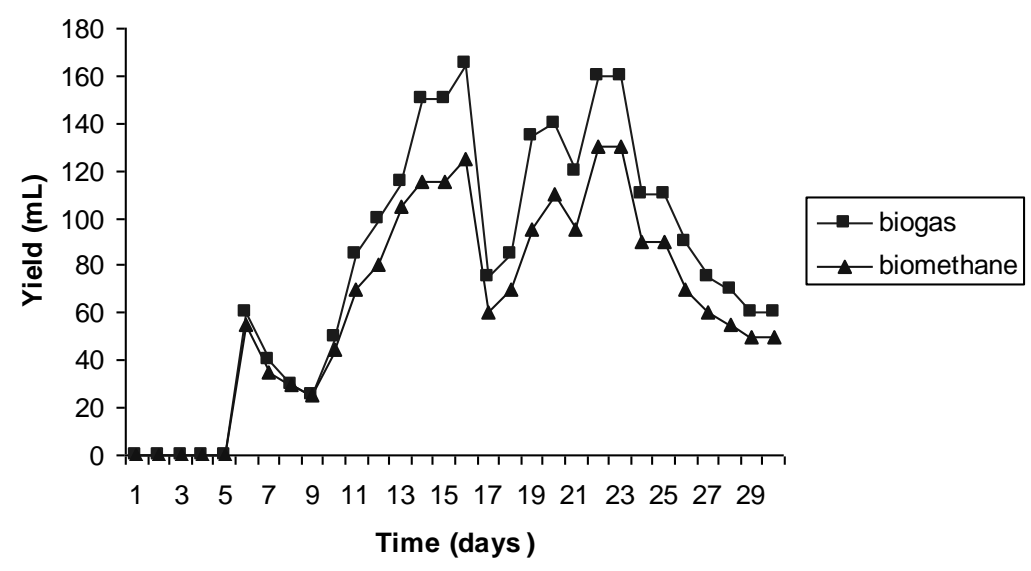

Fig. 1. Biogas/biomethane yielding rates of carpet grass (Axonopus fissifolius)

Documented evidence shows that biogas yield from grass is higher than that obtained from dairy cattle manure (Sidibe and Hashimoto 1990). While, according to Uzodinma and Ofoefule (2009), a mixture of grass and animal manure gives even higher biogas yields. Comparing the estimated biomethane potential (BMP) of carpet grass for a 120 day $\mathrm{AD}$ obtained here $\left(0.35 \mathrm{~m}^{3} \mathrm{CH}_{4} \mathrm{~kg}^{-1} \mathrm{TS}\right)$ with BMPs from other plant substrates obtained by other workers as listed by Lehtomaki (2006); vetch-oat mixture (0.37 $\mathrm{m}^{3} \mathrm{CH}_{4} \mathrm{~kg}^{-1} \mathrm{TS}$ ), carpet grass shows: a comparable BMP with Timothy-clover grass $\left(0.34 \mathrm{~m}^{3} \mathrm{CH}_{4} \mathrm{~kg}^{-1}\right.$ TS), Red canary grass $\left(0.33 \mathrm{~m}^{3} \mathrm{CH}_{4} \mathrm{~kg}^{-1} \mathrm{TS}\right)$; higher BMP than straw of oats $\left(0.29 \mathrm{~m}^{3} \mathrm{CH}_{4} \mathrm{~kg}^{-1} \mathrm{TS}\right)$, lupine 
$\left(0.29 \mathrm{~m}^{3} \mathrm{CH}_{4} \mathrm{~kg}^{-1} \mathrm{TS}\right)$, and willow $\left(0.28 \mathrm{~m}^{3} \mathrm{CH}_{4} \mathrm{~kg}^{-1}\right.$ TS), straw of rapeseed $\left(0.22 \mathrm{~m}^{3} \mathrm{CH}_{4} \mathrm{~kg}^{-1} \mathrm{TS}\right)$; and lower BMP than sugar beet $\left(0.4 \mathrm{~m}^{3} \mathrm{CH}_{4} \mathrm{~kg}^{-1} \mathrm{TS}\right)$. The proximity of the biogas and biomethane graphs in Figure 1 indicates high quality biogas (an average methane content of about $80.79 \%$ ). The total solids, volatile solids and $\mathrm{pH}$ of feedstock and digestate measured were $85.80 \%$ and $85.56 \%, 90.91 \%$ and $87.58 \%, 6.6\left(27^{0} \mathrm{C}\right)$ and $6.9\left(27^{\circ} \mathrm{C}\right)$ respectively. There was a low total solids and volatile solids removal which according to Francois et al. (2006) implies a relatively slow rate of biodegradation. The high ligno-cellulose content of "green biomass" and relatively limited anaerobic microbes available to digest lingo-cellulose during $\mathrm{AD}$ (McDonald et al. 1991) may have been responsible for the low total solids and volatile solids removal after anaerobic digestion; ligno-cellulose is recalcitrant to microbial attack during anaerobic digestion (Fan et al. 1981).

\section{Conclusions}

From the results obtained in this work, $42.7 \mathrm{~g}$ of fresh carpet grass clippings yielded $1.955 \mathrm{~L}$ of biomethane in a 30 day batch anaerobic digestion. Thus using the schemes of the "Biogas Project of LGED," 1 ton of fresh carpet grass clippings will yield about $121.6 \mathrm{~m}^{3}$ biomethane in a 120 days batch AD. If a single acre of carpet grass yields approximately 3 tons of clippings per annum, and 1 hectare is about 2.47 acres, it implies that one hectare of carpet grass lawn (about the size of a soccer pitch) will produce 7.41 tons grass clippings per annum. This means carpet grass will give an estimated biomethane potential of about $901.056 \mathrm{~m}^{3} \mathrm{CH}_{4} \mathrm{ha}^{-1} \mathrm{yr}^{-}$ ${ }^{1}$. These figures highlight the massive potential of carpet grass as a sustainable renewable energy resource. Anaerobic digestion is hence shown to be a profitable means of managing grass waste in particular and green waste by extension. The benefits of anaerobic digestion of carpet grass are seen to go beyond sanitation, but also in the generation of valuable resources, namely biogas and biofertiliser (digestate). An economically viable treatment method that will facilitate the digestion of the ligno-cellulose content of carpet grass thereby making available more volatile solids for biomethanation would further improve both biogas yield and total solids reduction; thus improving the economic viability of the entire AD process.

\section{References}

Abu-Dahrich, J., Orozco, A., Ahmad, M. And Rooney, D. 2011. The Potential of Biogas Production from Grass. In Proceedings of the Jordan International Energy Conference, Amman.

Al Seadi, T., Rutz, D., Prassl, H., Kottner, M., Finsterwalder, T., Volk, S. And Janssen, R. Biogas Handbook. University of Southern Denmark Esbjerg, niels Bohrs Vej 9-10. URL:
http://www.seai.ie/Renewables/Bioenergy/Biogas ha ndbook.pdf [Online: accessed 20th August 2012 4:46PM].

BIOGAS PROJECT - LGED (Local Government Engineering Department). URL:

http://api.ning.com/files/8Jqpk-Ot1iA17Q7Fjh*MUuGtbtBhigIS*qItk5WGPtG3niO7NTfHA11RsKnZ8zw7VdEINa 3TUb8YDaqsstLy0bmLegsw66/ChinDomeDesign.pdf [Online accessed: 22nd April 2013 2.22 PM].

Chynoweth, D., Owens, J. And Legrand, R. Renewable Methane from Anaerobic Digestion of Biomass. Renewable Energy, 2001, 22, p. 1-8. http://dx.doi.org/10.1016/S0960-1481(00)00019-7

De-Renzo, D. 1997. Energy from Bioconversion of Waste Materials. Noyes Data Cooperation, New Jersey, USA.

Deublein, D. And Steinhauser, A. 2008. Biogas from Waste and Renewable Resources: An Introduction. WileyVCH Verlog GmbH \& Co. KGaA, Germany.

Edelmann, W. Schleiss, K. And Joss, A. Ecological, Energetic and Economic Comparison of Anaerobic Digestion with Different Competing Technologies to Treat Biogenic Wastes. Water Science Technology, 2000, 41, p. 263-273.

Fan, L., Gharpuray, M. And Lee, Y. Evaluation of Pretreatments for Enzymatic Conversion of Agricultural Residues. Biotechnology and Bioenergy, 1981, 11, p.29-45.

FAOSTAT (verified December 2008). URL: http://faostat.fao.org/site/291/default.aspx. [Online: accessed 2 February 2012 3:15PM].

Francois, V., Feuillade, G., Skhiri, N., Lagier, T. And Matejka, G. Indicating the Parameters of the State of Degradation of Municipal Solid Waste. Journal of Hazardous Materials, 2006, 137(2), p. 1008-1015. http://dx.doi.org/10.1016/j.jhazmat.2006.03.026

Jensen, J. And Trager, W. Plasmodium falciparum in Culture: Use of Outdated Erythrocytes and Description of the Candle Jar Method. The Journal of Parasitology, 1977, 63(5), p. 883-886. http://dx.doi.org/10.2307/3279900

Kumar, S. 2012. Biogas. Intech, Rijeka, Croatia. http://dx.doi.org/10.5772/1793

Lehtomaki, A. 2006. Biogas Production from Energy Crops and Crop Residues, Jyvaskyla University Printing House, Jyvaskyla.

Mcdonald, P., Handerson, N. And Heron, S. 1991. The Biochemistry of Silage, $2^{\text {nd }}$ ed., Chalcombe Publications, Marlow, UK.

Mclaughlin, S., Garten, D., Lynd, C. Sanderson, M., Tolbert, V. And Wolf, D. High Value Renewable Energy from Prairie Grasses. Environmental Science and Technology, 2002, 36, p. 2122-2129. http://dx.doi.org/10.1021/es010963d

Murphy, J. And Power, N. An Argument for Using Biomethane Generated from Grass as a Biofuel in Ireland. Biomass and Bioenergy, 2008, 33, p. 504-512. http://dx.doi.org/10.1016/j.biombioe.2008.08.018

Nda-Umar, U. And Uzowuru, M. Anaerobic Codigestion of Fruit Waste and Abattoir Effluent. Journal of Biological Sciences and Bioconservation, 2011, 3, p. 31.

Pick, D., Dieterich, M. And Heintschel, S. Biogas Production Potential from Economically Usable Green Waste. Sustainability, 2012, 4, p.682-702. http://dx.doi.org/10.3390/su4040682

Pillai, S. 2009. A Comprehensive Laboratory Manual for Environmental Science and Engineering. New Age International Publishers Ltd, New Delhi, p. 7-11.

Prochnow, A., Heiermann, M., Plochl, M., Amon, T. And Hobbs, P. Bioenergy from Permanent Grassland- A Review. Biosource Technology, 2009, 100, p. 4945-4954. http://dx.doi.org/10.1016/j.biortech.2009.05.069 

Grass

Sidibe, A. And Hashimoto, A. 1990. Conversion of

Straw to Methane, p. 131-138. In Proceedings of the $6^{\text {th }}$ International Symposium on Agricultural and Process Wastes. ASAE, St. Joseph, MI, USA.

Thran, D. 2005. Sustainable Strategies for Biomass Use in the European Context. Final Report (verified December 2008). Institute for Energy and Environment, Leipzig.

Uzodinma, E., And Ofoefule, A. Biogas Production from Blends of Field Grass (Panicum maximum) with some Animal Wastes. International Journal of the Physical Sciences, 2009, 4(2), p. 91-95.

Walsh, M., Shapouri, D. And Slinsky, S. Bioenergy Crop Production in the United States. Environmental and Resource Economics, 2003, 24, p. 313-333. http://dx.doi.org/10.1023/A:1023625519092

Yu, Z., Morrison, M. And Schanbacher, F. 2010. Production and Utilization of Methane Biogas as Renewable Fuel. In Biomass to Biofuels: Strategies for Global Industries, p. 403-413. Wiley, UK.
M.Sc Chima NGUMAH - Federal University of Technology, Owerri. Department of Microbiology

Main research area: Bioconversion of biogenic waste to biogas and biofertiliser

Address: Department of Microbiology, Federal University of Technology, Owerri. P.M.B. 1526 Owerri. Nigeria.

Tel.: $\quad$ (234) 7062664079

E-mail: ccngumah@yahoo.com

Ph.D. Jude Ogbulie at the Department of Microbiology, Federal University of Technology, Owerri.

E-mail: ogbujuan@yahoo.com

Ph.D. Justina Orji at the Department of Microbiology, Federal University of Technology, Owerri.

E-mail:_chiookolo@yahoo.com

Ph.D Ekpewerechi Amadi at the Department of Microbiology,

Federal University of Technology, Owerri.

E-mail: $\quad$ amadies2001@yahoo.com

\title{
Paprastosios klosnès (Axonopus fissifolius) metanizavimas
}

\author{
C. Ngumah, J. Ogbulie, J. Orji. and E. Amadi \\ Federalinis technikos universitetas, Mikrobiologijos fakultetas, Nigerija
}

(gauta 2013 m. spalio mèn.; atiduota spaudai 2013 m. gruodžio mèn.)

\begin{abstract}
Axonopus fissifolius, iprastai vadinamai paprastaja klosne arba „kilimine žole“, buvo taikomas 30 paru anaerobinis apdorojimas. Anaerobinio pūdymo procesas buvo vykdomas serijinio padavimo sąlygomis, aplinkos temperatūrai esant $27-29^{\circ} \mathrm{C}$. Biometano matavimai buvo atliekami filtruoto sočiojo kalcio hidroksido tirpalo, laikomo skaidrioje kalibruotoje kolboje, apimties poslinkiui nustatyti. Iš $42,7 \mathrm{~g}$ šviežios susmulkintos paprastosios klosnès buvo gauta 1,9551 biometano. Per 30 dienų anaerobinio apdorojimo metu išgautas paprastosios klosnès biometano potencialas (BMP) buvo $0,05 \mathrm{~m}^{3} \mathrm{CH}_{4} \mathrm{~kg}^{-1} \mathrm{KD}$. Biometano potencialo normos pirma, antrą, trečią, ketvirta, penktą ir šeštą dienomis buvo atitinkamai $1,5 \mathrm{ml} \mathrm{g}^{-1} \mathrm{KD}(2,81$ proc.), $6,4 \mathrm{ml}$ $\mathrm{g}^{-1} \mathrm{KD}$ (14,58 proc.), $16,1 \mathrm{ml} \mathrm{g}^{-1} \mathrm{KD}$ (30,18 proc.), $17,74 \mathrm{ml} \mathrm{g}^{-1} \mathrm{KD}\left(33,25\right.$ proc.) ir $10,23 \mathrm{ml} \mathrm{g}^{-1}$ KD (19,81 proc.). Pramoniniu žaliavų ir pūdymo liekanų kietosios bei lakiosios dalelès ir $\mathrm{pH}$ buvo atitinkamai 85,80 proc. ir 85,56 proc., 90,91 proc. ir 87,58 proc, $6,6\left(27^{\circ} \mathrm{C}\right)$ ir $6,9\left(27^{\circ} \mathrm{C}\right)$. Gautas santykinai aukštas paprastosios klosnès biometano potencialas pasirinktoje aplinkos temperatūroje parodè, jog anaerobinis žolès atlieku pūdymas gali būti perspektyvi priemonè tvarkant šios rūšies atliekas - išlaikomos puikios sanitarinès sąlygos, taip pat yra išgaunamas biometanas. Toks biodujų išgavimas galètų būti ypač pelningas tropikuose, kur aplinkos temperatūra ịprastai visus metus yra tokia, kokios reikia optimaliai biometanacijai, dèl ko procesas dar lengviau prieinamas ir mažiau sudetingas.
\end{abstract}

